\title{
Comparison of measures of lead exposure, dose, and chelatable lead burden after provocative chelation in organolead workers
}

\author{
Brian S Schwartz, Michael P McGrail, Walter Stewart, Theresa Pluth
}

\begin{abstract}
Objectives-To describe $6 \mathrm{~h}$ urinary lead excretion (6 h PbU) after $1 \mathrm{~g}$ intravenous ethylene diamine tetraacetic acid (EDTA) in organolead manufacturing workers with mixed exposure to organic and inorganic lead; to determine the predictors of lead excretion (PbU); and to determine the extent to which internal lead stores and ongoing external exposure govern blood concentrations of lead
\end{abstract} (PbB).

Methods-A case series of 21 active workers were studied. Personal industrial hygiene data, grouped by 29 exposure zones, in combination with personal interviews about work location and times were used to derive several measures of recent and cumulative exposure to organic and inorganic lead. The average exposure intensities assigned to the 29 zones ranged from 4 to $119 \mu \mathrm{g} / \mathrm{m}^{3}$ $\left(0.02-0.57 \mu \mathrm{mol} / \mathrm{m}^{3}\right.$ as lead) for organic lead and from 1 to $56 \mu \mathrm{g} / \mathrm{m}^{3}(0 \cdot 004-0 \cdot 27$ $\mu \mathrm{mol} / \mathrm{m}^{3}$ ) for inorganic lead.

Results-After controlling for age, $6 \mathrm{~h}$ $\mathrm{PbU}$ was significantly and positively correlated with summary measures of $\mathrm{PbB}-$ for example, lifetime peak $\mathrm{PbB}$, time weighted $\mathrm{PbB}$-and zinc protoporphyrin concentrations-for example, lifetime peak zinc protoporphyrin, time weighted zinc protoporphyrin-but not with measures of estimated external exposure-for example, duration of exposure and cumulative exposure to inorganic or organic lead. Among workers with higher chelatable lead burdens (6 h PbU $\geqslant 212.4 \mu \mathrm{g}$ (1.03 $\mu \mathrm{mol})$ divided at the median), there was no apparent relation between recent inorganic lead exposure and $\mathrm{PbB}$ at the time of chelation. Among workers with lower chelatable lead burdens (6 h PbU < $212.4 \mu \mathrm{g}(1.03 \mu \mathrm{mol})$ however, there was a significant relation between exposure and effect between recent exposure to inorganic lead and PbBs.

Conclusion-These findings are consistent with the concept of physiological dampening. The high chelatable lead burden, a source of internal exposure, dampens the effect of external exposure on PbBs. The data suggest that in organolead workers with high chelatable lead burdens, PbBs may be more influenced by internal lead stores than by variations in airborne exposure to organic and inorganic lead.

(Occup Environ Med 1994;51:669-673)

Keywords: body burden; lead; provocative chelation; tetraethyl lead.

The organolead compounds most commonly encountered in the workplace are tetraethyl and tetramethyl lead, both components of additives for gasoline and aviation fuel. Use in the United States has greatly diminished since the introduction of catalytic converters into vehicles in 1975, but worldwide production and use is still considerable and represents an important occupational and environmental hazard. ${ }^{\prime}$

After absorption, tetraethyl lead is rapidly dealkylated primarily in the liver by cytochrome P-450 mixed function oxidases to the toxic metabolite triethyl lead, ${ }^{2-4}$ or possibly directly to inorganic lead. ${ }^{5}{ }^{6}$ Triethyl lead has been found to be relatively persistent in rodent tissues, with estimated half lives of 15 days in the liver and kidney, 7 days in the brain, and 3-5 days in blood. ${ }^{6}$ It is further metabolised to diethyl lead, an important urinary excretion product, then to inorganic lead, which can be excreted in the urine or stool, or stored in bone as the main portion of the body's burden of lead. ${ }^{4}$ Precipitable lead (inorganic lead) is produced rapidly, but it disappears rapidly from tissues, probably due to uptake by bones. ${ }^{5}$ Studies in humans suggest that such bone lead represents $95 \%$ of the body's burden of lead, ${ }^{7}$ with an estimated half life of elimination of 5-20 years. ${ }^{8}$

Although ethylene diamine tetraacetic acid (EDTA) does not chelate organolead compounds in vitro or in vivo, ${ }^{39}$ enhancement of urinary lead excretion (PbU) after EDTA treatment of patients with acute organolead poisoning has been documented in several case reports. ${ }^{9-13}$ Arai reported that in a worker with tetraethyl lead poisoning 22 days after exposure, $\mathrm{PbU}$ output was $51 \%$ inorganic, $43 \%$ diethyl lead, and $6 \%$ triethyl lead. ${ }^{9}$ Administration of EDTA resulted in increased urinary excretion of inorganic lead but not organic lead.

No previous studies have compared measures of exposure, dose, and chelatable lead burden in workers exposed to organolead. Although several case series have been 
reported concerning chelation in inorganic lead workers, exposure measures from epidemiological exposure assessment have not been used. In this study, the primary interest was to identify the determinants of blood lead concentrations ( $\mathrm{PbBs}$ ) in subjects exposed to lead. Specifically, we were interested in the extent to which internal lead stores and ongoing external exposure govern PbBs. A secondary aim was to describe lead excretion after administration of EDTA in organolead workers and determine the predictors of lead excretion in such workers.

\section{Materials and methods \\ STUDY POPULATION}

This case series consists of 21 employees of an organolead manufacturing facility in the eastern United States who sought medical care for possible health effects related to lead. All workers had mixed exposure to organic and inorganic lead and underwent provocative chelation with $1 \mathrm{~g}$ of intravenous EDTA. The population, one black and 19 white men and one white woman, had a mean (SD) age of $46.3(6.0)$ y. Details of the plant, the exposures in the area, and the study population have been reported in a study of the neurobehavioral effects of inorganic and organic lead exposure in a larger group of 222 organolead workers from the plant. ${ }^{14}$ Organolead exposure was estimated to represent $65-70 \%$ of total lead exposure in the area. The 21 workers who underwent diagnostic chelation were part of a larger group of 58 workers who were clinically evaluated at their own request.

All workers who underwent chelation had symptoms or diagnostic evidence of health effects to the central or peripheral nervous system-for example, on neuropsychological tests or nerve conduction studies-without another medical explanation. Because $\mathrm{PbB}$ is not thought to be a valid measure of cumulative lead absorption, diagnostic chelation was performed to aid in the clinical evaluations. Data were abstracted from the medical records and linked with previously collected epidemiological data ${ }^{14}$ with approval of the Institutional Review Board.

\section{COLLECTION OF DATA}

Demographic, medical, and occupational information was obtained by questionnaire and interview, as previously described. ${ }^{14}$ Provocative chelation was performed with $1 \mathrm{~g}$ of EDTA given intravenously in $500 \mathrm{ml}$ normal saline over $1 \mathrm{~h}$, followed by a $6 \mathrm{~h}$ urine collection. For all workers, $24 \mathrm{~h}$ lead excretion was estimated from the $6 \mathrm{~h}$ urinary lead excretion $(6 \mathrm{~h} \mathrm{PbU})$ value by the following equation: $24 \mathrm{~h}$ lead $(\mu \mathrm{g})=113.2+2.31 \times 6 \mathrm{~h}$ $\mathrm{PbU}(\mu \mathrm{g}) .^{15}$

MEASURES OF EXPOSURE AND DOSE

Several measures of work related external exposure to organic and inorganic lead and of internal dose were derived. ${ }^{14}$ Histories of individuals' exposure were derived after linkage of personal industrial hygiene data with daily hours worked, obtained by interview, in 29 exposure zones in the lead area of the plant, for all jobs ever held in the lead area. The personal industrial hygiene data, available from the previous 12 years but with half the samples from 1989-90, were grouped by exposure zone and the arithmetic mean was used as the summary measure of the intensity of exposure in the zone. The assigned exposure intensities in the 29 zones ranged from $4-119 \mu \mathrm{g} / \mathrm{m}^{3}$ $\left(0.02-0.57 \mu \mathrm{mol} / \mathrm{m}^{3}\right.$ as lead) for organic lead and $1-56 \mu \mathrm{g} / \mathrm{m}^{3} \quad\left(0.004-0.27 \mu \mathrm{mol} / \mathrm{m}^{3}\right)$ for inorganic lead. ${ }^{14}$

The exposure histories consisted of mixed exposure to inorganic and organic lead, and were estimated for 100 day employment intervals in $\mu \mathrm{g}$ days $/ \mathrm{m}^{3}$. The histories were used to create three main measures of external exposure: cumulative exposure to organic and inorganic lead during employment at the plant; recent (past 30 days) exposure to organic and inorganic lead; and lifetime weighted average intensity of exposure to organic and inorganic lead, dividing cumulative exposure by duration of exposure. Duration of exposure was also derived from the histories of exposure and was the final exposure variable to be assessed. Questionnaire data showed that no workers had occupational exposure to lead before employment in the plant or significant current or past non-occupational exposure to lead.

The $\mathrm{PbBs}, \mathrm{PbUs}$, and zinc protoporphyrin (ZPP) concentrations were monitored by the employer and were abstracted from plant medical records. These were used to derive three measures each for $\mathrm{PbU}, \mathrm{PbB}$, and $\mathrm{ZPP}$ : lifetime peak values; the corresponding measures obtained closest in time to chelation (PbUc, $\mathrm{PbBc}$, and $\mathrm{ZPPc}$ ); and time weighted measures.

The $\mathrm{PbBc}$ and $\mathrm{PbUc}$ were assayed by a NIOSH certified commercial laboratory with graphite furnace atomic absorption spectrophotometry. Most historical $\mathrm{PbBs}$ (from medical records) were assayed by anode stripping voltometry. Historical PbUs were generally assayed at the plant by a dithizone method (precipitate lead with phosphate collector; extract with chloroform; redissolve precipitate with acid, then alkalise; react with dithizone; assay with spectrophotometer). The ZPP assays were performed by haematofluorimetry. The historical PbUs and PbUcs provided total urinary lead of all forms.

\section{ANALYSIS OF DATA}

Data analysis was performed with the BMDP statistical software programs. $^{16}$ Detailed descriptive statistics and summary measures were derived for all variables. Bivariate scatterplots and correlation coefficients were determined for pairs of study variables. Multiple linear regression was used to identify predictors of $6 \mathrm{~h} \mathrm{PbU}$ and $\mathrm{PbBc}$. The $6 \mathrm{~h}$ $\mathrm{PbU}$ regressions examined the relative influence of inorganic $v$ organic lead exposure, recent $v$ cumulative exposure, and measures of external exposure $v$ internal dose, in the prediction of $6 \mathrm{~h} \mathrm{PbU}$. The $\mathrm{PbBc}$ regressions 
Table 1 Summary of demographic, clinical, exposure, and dose measures

\begin{tabular}{|c|c|c|}
\hline Characteristic & Mean (SD) & Range \\
\hline $\begin{array}{l}\text { Age }(\mathrm{y}) \\
\text { Height }(\mathrm{cm}) \\
\text { Weight }(\mathrm{kg}) \\
\text { Duration of exposure (y) } \\
\text { Lifetime peak PbB: }\end{array}$ & $\begin{array}{l}46(6) \\
180(7) \\
94(15) \\
14 \cdot 3(7 \cdot 4)\end{array}$ & $\begin{array}{l}38-59 \\
168-191 \\
66-125 \\
3 \cdot 3-26 \cdot 5\end{array}$ \\
\hline $\begin{array}{l}(\mu \mathrm{g} / \mathrm{dl}) \\
(\mu \mathrm{mol} / 1)\end{array}$ & $\begin{array}{l}33.6(13.0) \\
1.62(0.63)\end{array}$ & $\begin{array}{l}4 \cdot 0-56 \cdot 0 \\
0 \cdot 19-2 \cdot 71\end{array}$ \\
\hline $\begin{array}{l}\text { PbB just before chelation: } \\
(\mu \mathrm{g} / \mathrm{dl}) \\
(\mu \mathrm{mol} / \mathrm{l})\end{array}$ & $\begin{array}{l}20.6(6.5) \\
1.0(0.31)\end{array}$ & $\begin{array}{l}8 \cdot 0-30 \cdot 0 \\
0 \cdot 39-1 \cdot 45\end{array}$ \\
\hline \multicolumn{3}{|c|}{$\begin{array}{l}\text { Cumulative exposure during employment at plant: } \\
\text { To inorganic lead: }\end{array}$} \\
\hline $\begin{array}{l}\left(\mu \mathrm{g} \cdot \mathrm{y} / \mathrm{m}^{3}\right) \\
\left(\mu \mathrm{mol} \cdot \mathrm{y} / \mathrm{m}^{3}\right)\end{array}$ & $\begin{array}{l}255(125) \\
1.23(0.60)\end{array}$ & $\begin{array}{l}12-463 \\
0 \cdot 06-2 \cdot 24\end{array}$ \\
\hline $\begin{array}{l}\text { To organic lead (as lead) } \\
\left(\mu \mathrm{g} \cdot \mathrm{y} / \mathrm{m}^{3}\right) \\
\left(\mu \mathrm{mol} \cdot \mathrm{y} / \mathrm{m}^{3}\right)\end{array}$ & $\begin{array}{l}820(488) \\
3.96(2 \cdot 36)\end{array}$ & $\begin{array}{l}37-1807 \\
0 \cdot 18-8 \cdot 73\end{array}$ \\
\hline $\begin{array}{l}\text { Cumulative exposure, prev } \\
\text { To inorganic lead: }\end{array}$ & & \\
\hline $\begin{array}{l}\left(\mu \mathrm{g} \cdot \mathrm{y} / \mathrm{m}^{3}\right) \\
\left(\mu \mathrm{mol} \cdot \mathrm{y} / \mathrm{m}^{3}\right)\end{array}$ & $\begin{array}{l}2.2(1.6) \\
0.01(0.01)\end{array}$ & $\begin{array}{l}0-6.9 \\
0-0.03\end{array}$ \\
\hline $\begin{array}{l}\text { To organic lead (as lead) } \\
\left(\mu \mathrm{g} \cdot \mathrm{y} / \mathrm{m}^{3}\right) \\
\left(\mu \mathrm{mol} \cdot \mathrm{y} / \mathrm{m}^{3}\right)\end{array}$ & $\begin{array}{l}5.5(3.6) \\
0.03(0.02)\end{array}$ & $\begin{array}{l}0-12 \\
0-0.01\end{array}$ \\
\hline $\begin{array}{l}(\mu \mathrm{g}) \\
(\mu \mathrm{mol})\end{array}$ & $\begin{array}{l}215(129) \\
1.04(0.62)\end{array}$ & $\begin{array}{l}31-495 \\
0 \cdot 15-2 \cdot 39\end{array}$ \\
\hline
\end{tabular}

examined the relative influence of inorganic $v$ organic lead exposure in the prediction of $\mathrm{PbBc}$, and whether these most recent $\mathrm{PbBs}$ were more influenced by recent exposure or estimates of chelatable lead burden. Outliers were identified by examination of frequency distributions, scatterplots, and residual plots, and the influence of outliers on regression results was assessed. One outlier for recent inorganic lead exposure was eliminated from the analysis; the effect of this point on the regression is discussed in the results. Regressions were also evaluated for multicolinearity and departures from normality and were found to be free of these potential problems.

\section{Results}

The mean (SD) $6 \mathrm{~h} \mathrm{PbU}$ after $1 \mathrm{~g}$ of intravenous EDTA was 215 (129) $\mu \mathrm{g}(1.04(0.62)$ $\mu \mathrm{mol}$ ), with a range from 31 to $495 \mu \mathrm{g}$ (0.15-2.39 $\mu \mathrm{mol})$. The estimated mean (SD) $24 \mathrm{~h} \mathrm{PbU}$ was 609 (298) $\mu \mathrm{g}(2.94(1.44)$ $\mu \mathrm{mol})$, with a range of 184 to $1257 \mu \mathrm{g}$ (0.89-6.07 $\mu \mathrm{mol}$, table 1$)$. The $\mathrm{PbBcs}$ ranged from 8 to $30 \mu \mathrm{g} / \mathrm{dl}(0.39-1.45 \mu \mathrm{mol} / \mathrm{l})$, and study participants had a mean (SD) duration of exposure of $14.3(7 \cdot 4)$ years (table 1 ).

\section{PREDICTORS OF LEAD EXCRETION}

Age and duration of exposure were negatively correlated with $6 \mathrm{~h} \mathrm{PbU}$, whereas the measures of $\mathrm{PbB}$ (lifetime peak, $\mathrm{PbBc}$, and time weighted) and recent inorganic and organic lead exposure were positively correlated with $6 \mathrm{~h} \mathrm{PbU}$ (correlation matrix in table 2). Time weighted ZPP and lifetime peak ZPP were also correlated with $6 \mathrm{~h}$ PbU (Pearson's $r=0.62$ and 0.63 , respectively). Several exposure and $\mathrm{PbB}$ measures were negatively correlated with age (table 2), suggesting that older workers had less exposed jobs.

Multiple linear regression was used to examine the joint effects of predictor variables. No associations were found between any measure of external exposure and $6 \mathrm{~h}$ $\mathrm{PbU}$ after a control for age (table 3 ). With a control for age, lifetime peak $\mathrm{PbB}$ was an important predictor of $6 \mathrm{~h} \mathrm{PbU}$ (table 3); these two variables accounted for $53 \%$ of the variation in $6 \mathrm{~h} \mathrm{PbU}$. On average, the peak $\mathrm{PbB}$ was found $12 \cdot 1$ (8.7) years before chelation. Similar results were obtained for the other $\mathrm{PbB}$ measures ( $\mathrm{PbBc}$ and time weighted), but the total model $r^{2}$ was highest for peak $\mathrm{PbB}$. In the regression analyses,

Table 2 Correlation matrix of study variables

\begin{tabular}{|c|c|c|c|c|c|c|c|c|c|c|}
\hline & $\begin{array}{l}\text { Age } \\
(y)\end{array}$ & $\begin{array}{l}\text { Height } \\
(\mathrm{cm})\end{array}$ & $\begin{array}{l}\text { Weight } \\
(\mathrm{kg})\end{array}$ & $\begin{array}{l}\text { Duration of } \\
\text { exposure } \\
\text { (y) }\end{array}$ & $\begin{array}{l}\text { Lifetime } \\
\text { peak PbB } \\
(\mu g / d l)\end{array}$ & $\begin{array}{l}P b B c \\
(\mu g / d l)\end{array}$ & $\begin{array}{l}\text { CEINO } \\
\left(\mu g . y / m^{3}\right)\end{array}$ & $\begin{array}{l}\text { CEORG } \\
\left(\mu g . y / m^{3}\right)\end{array}$ & $\begin{array}{l}\text { RECINC } \\
\left(\mu g \cdot y / m^{3}\right)\end{array}$ & $\begin{array}{l}\text { O RECORG } \\
\text { 3) }\left(\mu g \cdot y / m^{3}\right)\end{array}$ \\
\hline $\begin{array}{l}\text { Age }(\mathrm{y}) \\
\text { Height }(\mathrm{cm}) \\
\text { Weight }(\mathrm{kg}) \\
\text { Duration of exposure }(\mathrm{y}) \\
\text { Lifetime peak } \mathrm{PbB}(\mu \mathrm{g} / \mathrm{dl}) \\
\text { PbBc }(\mu \mathrm{g} / \mathrm{dl}) \\
\text { CEINO }\left(\mu \mathrm{g} \cdot \mathrm{y} / \mathrm{m}^{3}\right) \\
\text { CEORG }\left(\mu \mathrm{g} \cdot \mathrm{y} / \mathrm{m}^{3}\right) \\
\text { RECINO }\left(\mu \mathrm{g} \cdot \mathrm{y} / \mathrm{m}^{3}\right) \\
\text { RECORG }\left(\mu \mathrm{g} \cdot \mathrm{y} / \mathrm{m}^{3}\right) \\
\text { 6h PbU }(\mu \mathrm{g})\end{array}$ & $\begin{array}{l}1 \cdot 0 \\
-0 \cdot 10 \\
0 \cdot 01 \\
0 \cdot 10 \\
-0 \cdot 16 \\
-0 \cdot 52^{\star} \\
-0 \cdot 40 \dagger \\
-0 \cdot 14 \\
-0 \cdot 57^{\star} \\
-0 \cdot 54^{\star} \\
-0 \cdot 47^{\star}\end{array}$ & $\begin{array}{l}1 \cdot 0 \\
0.58^{\star} \\
-0.22 \\
-0.01 \\
-0.03 \\
-0.19 \\
-0.25 \\
0.34 \\
0.19 \\
0.06\end{array}$ & $\begin{array}{c}1.0 \\
0.18 \\
0.18 \\
-0.15 \\
0.04 \\
0.16 \\
0.31 \\
0.41 \dagger \\
-0.09\end{array}$ & $\begin{array}{c}1.0 \\
-0.42 \dagger \\
-0.37 \\
0.54^{\star} \\
0.76^{\star} \\
-0.29 \\
-0.05 \\
-0.26\end{array}$ & $\begin{array}{c}1 \cdot 0 \\
0.78^{\star} \\
0.21 \\
-0.17 \\
0.63^{\star} \\
0.60^{\star} \\
0.65^{\star}\end{array}$ & $\begin{array}{c}1 \cdot 0 \\
0.25 \\
-0.15 \\
0.56^{\star} \\
0.45^{\star} \\
0.62^{\star}\end{array}$ & $\begin{array}{l}1.0 \\
0.73^{\star} \\
0.35 \\
0.40 \dagger \\
0.07\end{array}$ & $\begin{array}{l}1.0 \\
-0.03 \\
0.32 \\
-0.07\end{array}$ & $\begin{array}{l}1 \cdot 0 \\
0.66^{\star} \\
0.35\end{array}$ & $\begin{array}{l}1 \cdot 0 \\
0 \cdot 44^{\star}\end{array}$ \\
\hline
\end{tabular}

${ }^{\star} \mathrm{p}<0.05 ; \mathrm{tp}<0.1$.CEINO = cumulative exposure to inorganic lead during employment at plant; CEORG = cumulative exposure to organic lead during employment at plant; RECINO = cumulative exposure to inorganic lead in the 30 days before chelation RECORG = cumulative exposure to organic lead in the 30 days before chelation.

Table 3 Results of multiple linear regressions modelling $6 \mathrm{hPbU}(\mu \mathrm{g})$ after $1 \mathrm{~g}$ intravenous EDTA, comparing measures of exposure and dose

\begin{tabular}{|c|c|c|c|c|}
\hline Model & Variable & $\beta(S E \beta)^{*}$ & $P$ valuet & Total model $r^{2}$ \\
\hline $\begin{array}{l}\text { Recent exposure to organic } \\
\text { lead and age }\end{array}$ & $\begin{array}{l}\text { RECORG }\left(\mu \mathrm{g} \cdot \mathrm{y} / \mathrm{m}^{3}\right) \\
\text { Age }(\mathrm{y})\end{array}$ & $\begin{array}{r}9 \cdot 33(8 \cdot 50) \\
-7 \cdot 15(5 \cdot 10)\end{array}$ & $\begin{array}{l}0.29 \\
0.18\end{array}$ & $0 \cdot 27$ \\
\hline Recent exposure to inorganic & RECINO ( $\left.\mu \mathrm{g} \cdot \mathrm{y} / \mathrm{m}^{3}\right)$ & $\begin{array}{r}9.79(20.76) \\
-8.70(5.38)\end{array}$ & $\begin{array}{l}0.64 \\
0.12\end{array}$ & 0.23 \\
\hline $\begin{array}{l}\text { Duration of exposure } \\
\text { and age }\end{array}$ & $\begin{array}{l}\text { Duration of exposure (y) } \\
\text { Age }(y)\end{array}$ & $\begin{array}{l}-3.85(3.54) \\
-9.69(4.33)\end{array}$ & $\begin{array}{l}0.12 \\
0 \cdot 29 \\
0.04\end{array}$ & 0.27 \\
\hline $\begin{array}{l}\text { Lifetime peak } \mathrm{PbB} \\
\text { and age }\end{array}$ & $\begin{array}{l}\text { Lifetime peak } \mathrm{PbB}(\mu \mathrm{g} / \mathrm{dl}) \\
\text { Age }(\mathrm{y})\end{array}$ & $\begin{array}{r}5.23(1.57) \\
-6.59(3.57)\end{array}$ & $\begin{array}{r}<0.01 \\
0.08\end{array}$ & 0.53 \\
\hline
\end{tabular}

$\star \operatorname{SE} \beta=\mathrm{SE}$ of $\beta$ coefficient; $+\mathrm{P}$ value from $\mathrm{t}$ test of $(\beta$ coefficient/SE $\beta)$. Abbreviations as for table 2 . 
Table 4 Results of multiple linear regression results models $\mathrm{PbBc}$

\begin{tabular}{|c|c|c|c|c|}
\hline Model & Variable & $\beta(S E \beta)^{*}$ & $P$ value $\dagger$ & Total model $r^{2}$ \\
\hline $\begin{array}{l}\text { Chelatable lead, } \\
\text { recent exposure to inorganic lead, } \\
\text { and age } \\
\text { Chelatable lead, } \\
\text { recent exposure to inorganic lead, } \\
\text { and duration of exposure } \\
\text { To evaluate influence of } \\
\text { recent exposure to inorganic lead } \\
\text { in workers with } \\
\text { high and low chelatable } \\
\text { lead burdens }\end{array}$ & $\begin{array}{l}\text { 6hPbU }(\mu \mathrm{g}) \\
\text { RECINO }\left(\mu \mathrm{g} \cdot \mathrm{y} / \mathrm{m}^{3}\right) \\
\text { Age }(\mathrm{y}) \\
6 \mathrm{hPbU}(\mu \mathrm{g}) \\
\text { RECINO }\left(\mu \mathrm{g} \cdot \mathrm{y} / \mathrm{m}^{3}\right) \\
\text { Duration of exposure (y) } \\
\text { Cheldi } \\
\text { Interaction } \dagger \\
\text { RECINO }\left(\mu \mathrm{g} \cdot \mathrm{y} / \mathrm{m}^{3}\right) \\
\text { Duration of exposure (y) }\end{array}$ & $\begin{array}{r}0.025(0.011) \\
1.620(0.886) \\
-0.020(0.258) \\
0.024(0.009) \\
1.490(0.730) \\
-0.170(0.154) \\
12.31(3.463) \\
-3.28(1.419) \\
3.50(1.105) \\
-0.21(0.148)\end{array}$ & $\begin{array}{l}0.03 \\
0.09 \\
0.94 \\
0.02 \\
0.06 \\
0 \cdot 28 \\
<0.001 \\
0.04 \\
0.01 \\
0 \cdot 17\end{array}$ & 0.53 \\
\hline
\end{tabular}

Cheldi $=$ chelatable lead burden based on $6 \mathrm{~h}$ chelation result, dichotomised at the median (Cheldi $=1$ if $6 \mathrm{hPbU} \geqslant 212 \cdot 4 \mu \mathrm{g}$ $(1.03 \mu \mathrm{mol})$ and Cheldi $=0$ if $6 \mathrm{hPbU}<212.4 \mu \mathrm{g}(1.03 \mu \mathrm{mol}) ;$ Interaction $=$ Cheldi $\times$ RECINO; $\mathrm{t}$ (association of $\mathrm{PbBc}$ and RECINO is different for subjects with high and low chelatable lead burdens, as estimated by $6 \mathrm{hPbU}$ ). Other footnotes as for table 3 .

height, weight, cigarette smoking, renal function, and job title were not associated with $6 \mathrm{~h}$ $\mathrm{PbU}$.

PREDICTORS OF BLOOD LEAD AT THE TIME OF CHELATION

In bivariate analyses, $\mathrm{PbBc}$ was positively correlated with recent organic and inorganic lead exposure (table 2); and lifetime weighted average intensity of exposure to total $(r=0.48, P=0.03)$ and inorganic $(r=0.64$, $\mathrm{P}=0.003$ ) lead. The $\mathrm{PbBc}$ was negatively correlated with age and exposure duration. In multiple linear regression analyses, recent inorganic lead exposure and chelatable lead burden (6 h PbU) were both independent predictors of $\mathrm{PbBc}$ (table 4 ).

An interesting association was found among chelatable lead burden, recent inorganic lead exposure, and $\mathrm{PbBc}$. With control for duration of exposure among workers with high chelatable lead burdens $(6 \mathrm{~h}$ PbU $\geqslant 212.4 \mu \mathrm{g}(1.03 \mu \mathrm{mol})$, divided at the median), there was no apparent relation between recent inorganic lead exposure and $\mathrm{PbBc}$, whereas among workers with low chelatable lead burdens ( $6 \mathrm{~h} \mathrm{PbU}<212.4 \mu \mathrm{g}$ $(1.03 \mu \mathrm{mol}))$ there was a dose-related increase in $\mathrm{PbBc}$ with increasing recent inorganic lead exposure (table 4$)$. The 11 workers with high chelatable lead burdens $(6 \mathrm{~h} \mathrm{PbU}=212.4 \mu \mathrm{g}$ ( $1.03 \mu \mathrm{mol}$ )) had an estimated mean (SD) 24 h PbU of $842(184) \mu \mathrm{g}(4.07(0.89) \mu \mathrm{mol})$

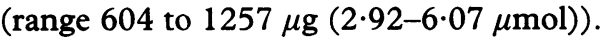

One outlier for recent inorganic lead exposure was identified. When this point was eliminated from the linear regression model of $\mathrm{PbBc}$, there were no changes in the $\beta$ coefficients in the model, but the SE of the interaction term increased and hence the significance declined from $P=0.04$ to $P=0 \cdot 11$.

\section{Discussion}

Despite modest rises in $\mathrm{PbBs}$, over half of 21 organolead workers evaluated for possible health effects related to lead had high chelatable lead burdens. At the time of chelation, $\mathrm{PbBs}$ ranged from 17 to $30 \mu \mathrm{g} / \mathrm{dl}(0 \cdot 82-1 \cdot 45$ $\mu \mathrm{mol} / \mathrm{l}$ ) in the 11 workers with $24 \mathrm{~h} \mathrm{PbUs}$ estimated to be $>600 \mu \mathrm{g}(2.90 \mu \mathrm{mol})$, a generally accepted positivity criterion. ${ }^{15}$ Even with low $\mathrm{PbBs}$, several measures of $\mathrm{PbB}$ were strongly associated with chelatable lead burden in this group of workers
The data suggest that among workers with high chelatable lead burdens, recent inorganic lead exposure does not exert a strong influence on $\mathrm{PbBs}$. In contrast, among workers with low chelatable lead burdens, recent inorganic lead exposure is an important predictor of $\mathrm{PbBc}$, and the data show a strong relation between exposure and effect. Caution must be expressed, however, because the significance, but not the magnitude, of this association declined after the elimination of a single outlier for recent inorganic lead exposure.

This finding would be expected for toxins with long half lives of elimination $\left(t_{1 / 2}>40 \mathrm{~h}\right)$, and is consistent with the concept of physiological dampening. The high chelatable lead burden, a source of internal exposure, dampens the transmission of external exposure variations to $\mathrm{PbBs} .{ }^{17}$ The relative contributions of internal lead stores and recent lead exposure to $\mathrm{PbBs}$ found in this study contrasts with findings by other investigators that $\mathrm{PbB}$ is more influenced by daily lead absorption than by lead released from bone deposits. ${ }^{18}$

Measures of external lead exposure (cumulative or recent inorganic or organic lead exposure) were not significant predictors of chelatable lead stores. Measures of internal dose $(\mathrm{PbB})$ were expected to be better predictors of chelatable lead stores than external exposure measures because of their ability to account for all routes of exposure, sources of exposure-for example, non-vocational inorganic lead exposure - and use of personal protective equipment. Also, $\mathrm{PbB}$ is likely to be in equilibrium with these chelatable lead stores.

Although negatively correlated $(r=$ $-0 \cdot 26$ ), the association between $6 \mathrm{~h} \mathrm{PbU}$ and duration of exposure was not significant. For toxins with long elimination half lives, duration of exposure is thought to be a good surrogate for cumulative dose, and hence retained body burden. ${ }^{17}$ Data on associations between duration of exposure and provocative chelation results are scant, but some suggest that duration of exposure is a predictor of chelation yield in workers exposed to inorganic lead. ${ }^{1819}$ It is possible that chelatable lead stores are not an accurate reflection of body burden, ${ }^{20}$ which perhaps accounts for this lack of association.

Lead kinetic studies have shown that the 
half life of lead varies among its storage compartments. ${ }^{821}$ The elimination of lead from trabecular bone, for example, is more rapid than from cortical bone, ${ }^{22}$ and the rate of elimination of lead stores decreases with time. ${ }^{23} 24$ Postmortem analysis has suggested that with advancing age an increasing proportion of bone lead content is stored in cortical bone rather than trabecular bone. ${ }^{25}$ This would suggest that chelation yields may decrease over time, and hence with advancing age and increasing duration of exposure. We can not be certain that the finding that older workers had lower $\mathrm{PbU}$ is because of decreased availability of lead stores to EDTA, or because older workers in this study had lower recent exposures to inorganic and organic lead.

\section{Conclusions}

Provocative chelation showed high chelatable lead burdens in 11 of 21 organolead workers with an average of 14 years of exposure in the industry. The PbU after intravenous EDTA was not strongly associated with any measure of external exposure to inorganic and organic lead after control for age. Lifetime peak $\mathrm{PbB}$, to a lesser degree other blood lead measures, and age accounted for over $50 \%$ of the variability in chelation results in multiple linear regression analyses. The $\mathrm{PbBs}$ were found to be independently influenced by both recent inorganic lead exposure and internal lead stores, but workers with high chelatable lead burdens did not show increases in $\mathrm{PbBs}$ with increasing recent exposure to inorganic lead.

1 Grandjean P. Health significance of organolead compounds. In: Rutter M, Jones RR, eds. Lead versus health sources and effects of low level lead exposure. New York: John Wiley, 1983:179-90.

2 Ferreira da Silva D, Schröder U, Diehl H. Metabolism of tetraorganolead compounds by rat-liver microsoma mono-oxygenase. II. Enzymic dealkylation of tetraethyl lead. Xenobiotica 1983;13:583-90.

3 Cremer J. Biochemical studies on the toxicity of tetraethyl lead and other organolead compounds. $\mathrm{Br} F$ Ind Med 1959;16:191-9.

4 Grandjean P, Nielsen T. Organolead compounds: environmental health perspectives. Residue Reviews 1979;72:98-148.

5 Bolanowska W. Distribution and excretion of triethyl lead in rats. Br f Ind Med 1968;25:203-8.

6 Hayakawa $\mathrm{K}$. Microdetermination and dynamic aspects of alkyl lead compounds in vivo. Part II. Studies on the dynamic aspects of alkyl lead compounds in vivo. fapanese fournal of Hygiene 1972;26:526-39.

7 Barry P, Mossman D. Lead concentrations in human tissues. $\mathrm{Br} \mathcal{F}$ Ind Med 1970;27:339-51.

8 Hryhorczuk D, Rabinowitz M, Hessl S, Hoffman D Hogan M, Mallin K, et al. Elimination kinetics of blood lead in workers with chronic lead intoxication. $A m \mathcal{F}$ Ind Med 1985;8:33-42.

9 Arai F. Determination of triethyllead, diethyllead, and inorganic lead in urine by atomic absorption spectrometry. Ind Health 1986;24:139-50.

10 Boyd P, Walker G, Henderson I. The treatment of tetraethyl lead poisoning. Lancet 1957;i:181-5.

11 Gething J. Tetramethyl lead absorption: a report of human exposure to a high level of tetramethyl lead. $B r F$ Ind Med 1974;32:329-33.

12 Robinson R. Tetraethyl lead poisoning from gasoline sniffing. $\mathcal{F} A M A$ 1978;240:1373-4.

13 Hansen $\mathrm{K}$, Sharp F. Gasoline sniffing, lead poisoning, and myoclonus. $F A M A$ 1978;240:1375-6.

14 Schwartz BS, Bolla KI, Stewart W, Ford DP, Agnew J, Frumkin H. Decrements in neurobehavioral performance associated with mixed exposure to organic and inorganic lead. $A m \mathcal{F}$ Epidemiol 1993;137:1006-21.

15 Sokas R, Atleson J, Keogh JP. Shortened forms of provocative lead chelation. F Occup Med 1988;30:420-4

16 Dixon WJ, ed. BMDP statistical software manual. Vols and 2. Berkeley: University of California Press, 1990.

17 Rappaport S. Assessment of long-term exposures to toxic substances in air. Ann Occup Hyg 1991;35:61-121.

18 Corsi G, Bartolucci GB. Biological monitoring of worker with past lead exposure: biochemical findings. Scand $f$ with past lead exposure: biochemical

19 Brangstrup Hansen JP, Døssing M, Paulev P-E Chelatable lead body burden (by calcium-disodium EDTA) and blood lead concentration in man. $f$ Occup Med 1981;23:39-43.

20 Tell I, Somervaille LJ, Nilsson U, Bensryd I, Schutz A Chettle DR, et al. Chelated lead and bone lead. Scand $\mathcal{F}$ Work Environ Health 1992;18:113-9.

21 Rabinowitz M, Wetherill G, Kopple J. Kinetic analysis of lead metabolism in healthy humans. $\mathcal{f}$ Clin Invest 1976; 58:260-70.

$22 \mathrm{Hu} \mathrm{H}$, Pepper L, Goldman R. Effect of repeated occupational exposure to lead, cessation of exposure, and chelational exposure to lead, cessation of exposure, and chela-
tion on levels of lead in bone. Am $\mathcal{F}$ Ind Med 1991; 20:723-35.

23 Marcus A. The body burden of lead: comparison of mathematical models for accumulation. Environ Res 1979;19: 79-90.

24 Christofferson J, Ahlgren L, Schutz A, Skerfving S. Decrease of skeletal lead levels in man after end of occupational exposure. Arch Environ Health 1986;41:312-8.

25 Gross SB, Pfitzer E, Yeager D, Kehoe RA. Lead in human tissues. Toxicol Appl Pharmacol 1975;32:638-51. 